\title{
Applied Entomology and Zoology Vol. 52, No. 2 目次
}

(2017 年 5 月 25 日発行)

\section{REVIEW}

Invasion of Japan by exotic leafminers Liriomyza spp. (Diptera: Agromyzidae) and its consequences [外来ハモグリ バエ Liriomyza spp. (ハエ目：ハモグリバエ科)による日本への侵 入とその結果]

Yoshihisa Abe (阿部芳久) 175

\section{ORIGINAL RESEARCH PAPERS}

Insecticidal activities of methyleugenol and $\boldsymbol{\beta}$-asarone, from the herbal medicines Saishin and Sekisho-kon, and other alkoxy-propenyl-benzene derivatives against the cigarette beetle Lasioderma serricorne (Coleoptera: Anobiidae) [細幸 ·

石菖根から単離されたメチルオイゲノール・ $\beta$-アサロンと類縁 アルコキシプロペニルベンゼン類のタバコシバンムシ (コウチュ ウ目：シバンムシ科) に対する殺虫活性]

Toshihiro Imai, Ryota Masuda (今井利宏・増田亮太)

Influence of olive variety on biological parameters of Bactrocera oleae (Diptera: Tephritidae) [オリーブの品種がオ リーブミバエ (ハエ目：ミバエ科) の生物学的パラメータに及ぼ す影響]

Nikos Garantonakis, Kyriaki Varikou, Athanasia Birouraki 189

Ants (Hymenoptera: Formicidae) as potential egg predators of lepidopteran pests of sweet potato, Ipomoea batatas (Solanales: Convolvulaceae), in Japan [日本においてサッマ イモ (ナス目：ヒルガオ科)を加害するチョウ目害虫卵の潜在的 捕食者としてのアリ (ハチ目：アリ科)について]

Hiroshi Suenaga（末永 博） 197

Adenosine triphosphate assay of Bactrocera dorsalis (Diptera: Tephritidae) eggs treated with low or high temperatures [低温又は高温で処理されたミカンコミバエ（ハエ目： ミバエ科) 卵の ATP 量分析]

Toshihisa Kamiji, Masashi Kadoi (上地俊久 · 加土井 仁) 209

Invasion dynamics of Asian hornet, Vespa velutina (Hymenoptera: Vespidae): a case study of a commune in south-west France[ツマアカスズメバチ (ハチ目:スズメバチ科) の侵入動態：南西フランスの 1 行政区の事例]

Daniel N. Franklin, Mike A. Brown, Samik Datta, Andrew G. S. Cuthbertson, Giles E. Budge, Matt J. Keeling 221
Establishment and yearly/seasonal occurrence of the exotic coccidophagous ladybird Cryptolaemus montrouzieri (Coleoptera: Coccinellidae) in citrus groves in Shizuoka City, central Japan: a 5-year survey on adult numbers [静 岡市の相橘園に打ける外来種ツマアカオオヒメテントウの定着と 年次および季節消長 : 5 年間の成虫数調査]

Shuji Kaneko（金子修治） 231

Assessment of genetic diversity and differentiation of Liposcelis bostrychophila (Psocoptera: Liposcelidae) in China using inter-simple sequence repeat (ISSR) fingerprinting [ISSR 領域の DNA フィンガープリンティング法による 中国でのチャタテムシ目の 1 種 Liposcelis bostrychophila の遺伝的 多様性と分化]

En-Tao Sun, Yi-Nan Wang, Kang Wang, Shu-Jun Xu, DanYang Nan, Wen-Jie Chen, Ying-Ying Zhang 241

Mitochondrial sequence polymorphism in Chinese populations of Hylobitelus xiaoi (Coleoptera: Curculionidae) [Hylobitelus xiaoi (コウチュウ目：ゾウムシ科)の中国個体群にお けるミトコンドリアゲノム多型]

Haiyan Zhang, Shengli Zhang, Yang Zhang, Linping Zhang, Dong Li, Longxi He, Fenggang Luan 247

The influence of feeding and host deprivation on egg load and reproduction of an aphid parasitoid, Aphidius gifuensis (Hymenoptera: Braconidae) [ギフアブラバチ (ハチ目 : コマユバ チ科)に扔いて摂食や寄主除去が産卵数扎よび生殖に及ぼす影響]

Ming-Zhen Pan, Li Wang, Chen-Yang Zhang, Lin-Xi Zhang, Tong-Xian Liu $\mathbf{2 5 5}$

The influence of geographic population, age, and mating status on the flight activity of the Asian gypsy moth Lymantria dispar (Lepidoptera: Erebidae) in China [中国の アジア型マイマイガ (チョウ目：トモエガ科)に打いて個体群, 日齢抢よび交尾状態が飛翔行動に及ぼす影響]

Fan Yang, Youqing Luo, Juan Shi 265

The major constituents of the venom gland of a braconid endoparasitoid, Meteorus pulchricornis (Hymenoptera: Braconidae) [内部寄生蜂ギンケハラボソコマユバチ (ハチ目 : コマユバチ科)の毒液腺の主要構成要素]

Kakeru Yokoi, Takeshi Sano, Masahiro Suzuki, Toshiharu 
Tanaka, Chieka Minakuchi, Ken Miura（横井 翔·佐野健志 · 鈴木正洋·田中利治·水口智江可 · 三浦 健） 271

Life history and life table of the host-feeding parasitoid Hemiptarsenus varicornis (Hymenoptera: Eulophidae) [寄主 摂食 (host-feeding) を行う寄生蜂カンムリヒメコバチ (ハチ目： ヒメコバチ科) の生活史と生命表]

Xiao-Qin Cheng, Feng-Qin Cao, Yi-Bo Zhang, Jian-Yang Guo, Fang-Hao Wan, Wan-Xue Liu 287

Reproduction of Aphidoletes aphidimyza (Diptera: Cecidomyiidae) on a banker plant system of sorghum with Melanaphis sacchari (Hemiptera: Aphididae) and its oviposition selection between this system and eggplant with Aphis gossypii (Hemiptera: Aphididae) [ヒエノアブラムシ (カメムシ 目：アブラムシ科) の存在するソルガムのバンカー植物システム に打けるショクガタマバエ (ハエ目：タマバエ科)の増殖打よび このシステムとワタアブラムシの存在するナスの間の産卵選択］

Keita Higashida, Eizi Yano, Hiroaki Toyonishi, Miku Nakauchi, Junichiro Abe (東田景太 · 矢野栄二 ·豊西宏章 · 中内未来 · 安部 順一朗） 295

Changes in defense allomone compositions of Eutrichodesmus elegans and Eutrichodesmus armatus (Polydesmida: Haplodesmidae) during different stages of their life cycles [ウチカケヤスデとヒメヨロイヤスデ (オビヤスデ目) の防御分泌 物組成について，全成長過程にわたる変化］

Yasumasa Kuwahara, Tsutomu Tanabe, Yasuhisa Asano (桑原 保正・田邊 力・浅野泰久） 305

Relationship between temperature and development rate of Copitarsia incommoda (Lepidoptera: Noctuidae) in the Bolivian Andes[ボリビアのアンデス地方に生息する Copitarsia incommoda (チョウ目：ヤガ科) の成長速度と気温との関係] F. Rebaudo, Q. Struelens, F. Callizaya Condori, R. Quispe 313

Trypsinized Cry1Fa and Vip3Aa have no detrimental effects on the adult green lacewing Chrysopa pallens (Neuroptera: Chrysopidae) [トリプシン処理された Bt 毒素 Cry1Fa および Vip3Aa は，ヨツボシクサカゲロウ（アミメカゲロウ目：クサカゲ ロウ科) 成虫に有害な影響を及ぼさない]

Intazar Ali, Shuai Zhang, Muhammad Iqbal, Samina Ejaz, Jinjie Cui 321
Soldiers are differentiated from male larval stages in incipient colonies of Nasutitermes takasagoensis (Isoptera: Termitidae) [タカサゴシロアリ（シロアリ目：シロアリ科）の初 期コロニーにおける雄幼虫からの兵隊分化］

Kouhei Toga, Chieka Minakuchi, Kiyoto Maekawa(栂 浩平 . 水口智江可・前川清人） 329

Do the amount of sex pheromone and frequency of calling behavior in females affect the mate-searching behavior of males in Dasylepida ishigakiensis (Coleoptera: Scarabaeidae)? [ミヤコケブカアカチャコガネ (コウチュウ目 : コガネムシ科) のオスの配偶者探索行動に性フェロモンの量およ びメスのコーリング経験回数は影響するか? ]

Hiroe Yasui, Nao Fujiwara-Tsujii, Seiji Tanaka, Sadao Wakamura, Norio Arakaki (安居拓恵 - 辻井 (藤原) 直 - 田中誠 二・若村定男・新垣則雄） 337

\section{TECHNICAL NOTES}

A method for rearing the yellow-spotted longicorn beetle, Psacothea hilaris (Coleoptera: Cerambycidae), to stabilize the last larval instar [キボシカミキリ（コウチュウ目：カミキ リムシ科) 幼虫の終齢を揃えるための飼育方法]

Keisuke Nagamine, Yukio Ishikawa, Sugihiko Hoshizaki (長峯 啓祐・石川幸男・星崎杉彦) 345

Evaluation of easy, non-destructive methods of DNA extraction from minute insects[微小昆虫からの簡単な非破壊 DNA 抽出法の評価]

Kazuki Miura, Yoshimitsu Higashiura, Kaoru Maeto (三浦一 芸・東浦祥光・前藤 薰) 349

Molecular evaluation of diamide resistance in diamondback moth (Lepidoptera: Yponomeutidae) populations using quantitative sequencing [量的シーケンシングを用いたコナガ (チョウ目：スガ科) 個体群のジアミド剤抵抗性の分子評価]

S. Sonoda, K. Inukai, S. Kitabayashi, S. Kuwazaki, A. Jouraku （園田昌司 · 犬飼佳代 · 北林 聡 - 桑崎誠剛 · 上樂明也） 353

\section{ERRATUM}

Erratum to: The number of stripes on the compound eyes reflects each instar in Acromantis satsumensis (Mantodea: Hymenopodidae) [正誤表 : サツマヒメカマキリ（カマキリ目 : 八ナカマキリ科) に打ける各齢期と複眼縞模様数の関係]

Hiroshi Nakamine, Kazuhisa Yamasaki, Hideshi Naka (中 峰 空·山崎和久 · 中 秀司） 359 